\title{
Evaluation of Sanitary Conditions in Kuje Market in Abuja, Nigeria with Diverse Cultural Practices and Provision of a Dry Ecological Toilet System
}

\author{
Francis Eremutha A. ${ }^{1}{ }^{*}$ Hammed Taiwo B. ${ }^{2}$, Sridhar Mynepalli K. C. ${ }^{2}$ and Aluko Olufemi O. ${ }^{3}$ \\ ${ }^{1}$ Women Friendly Initiative (WFI), WFI Close, Plot 85A, AA1, Employment Area, Kuje, Abuja, Nigeria \\ ${ }^{2}$ Department of Environmental Health Sciences, University of Ibadan, Ibadan, Nigeria \\ ${ }^{3}$ Department of Community Health, Faculty of Clinical Sciences, Obafemi Awolowo University, Ile Ife, Nigeria
}

Copyright $\bigcirc 2016$ by authors, all rights reserved. Authors agree that this article remains permanently open access under the terms of the Creative Commons Attribution License 4.0 International License

\begin{abstract}
This paper presents the general sanitation practices by the traders in a major market in Kuje located in the Federal Capital Territory (FCT), Abuja and our efforts in reorientating the market stakeholders towards the provision and use of a new dry sanitation toilet complex. The market is known for its diversity in Nigerian ethnicity, culture and the variety of goods and services. A novel toilet complex was designed and built which has the following features: 8 toilet units (4 each for male and female), urine diversion, a gender-segregated urinal, a urine storage tank, used menstrual absorbents disposal facility for women, bathing facility and a composting chamber for organic fertilizer production from the generated faecal matter and market wastes. The design also made provision for culturally sensitive persons to use a small spray of water for anal cleaning. There was provision for hand washing with soap. The respondents provided baseline information that enbled the design features through 5 Key Informant Interviews (KIIs) and 2 Focus Group Discussions (FGDs). This was followed by interviewed administered, semi-structured questionnaire which utilized a total sampling approach where the owners of all the 199 lock-up and open stalls in the market were enrolled and participated in the study. The mean age of the respondents was $34.3 \pm 9.7$ years and $55.8 \%$ were females. The sources of water in the market were: hand dug well $(11.7 \%)$, borehole $(37.6 \%)$, water vendor $(41.6 \%)$ and sachet water $(9.1 \%)$. The market has three existing toilets that were mostly patronized by males. Due to poor maintenance of the existing toilets, women preferred open defecation and use of potty in their stalls, disposed with solid wastes. Most respondents $(80.7 \%)$ were willing to pay and use the newly built dry toilet in the market as they perceive aesthetics $(28.9 \%)$, cleanliness $(21.8 \%)$ and disease prevention $(6.6 \%)$ as major benefits. The toilet design serves as a model for other public institutions where sanitation is compromised. The market community owns, operates and maintains the facility and the user charges are levied for sustainability.
\end{abstract}

Keywords Dry Toilet, Market Community, Composting Chamber, Urine Diversion, Organic Fertilizer, Open Defecation

\section{Introduction}

According to WHO [1], about 1.1 billion people globally do not have access to improved water supply, including pipe borne water that was heratic in the study area. The global sanitation crisis was recognized by the international community with the Millennium Development Goals (MDGs) 7, target 10 that soughtto halve the proportion of people without sustainable access to basic sanitation by 2015 [2]. Nigeria missed the target and in the current dispensation of the Sustainable Development Goals (SDGs), there has been no visible and concrete framework, plan and commitments in Nigeria towards meeting SDG 6 that seek to eradicate open defecation by 2030 . The situation has also been agravated by the economic depression, which has affected the implementation of planned water and sanitation interventions in the Country. The lack of access to basic sanitation facilities, coupled with poor hygiene practices has been responsible for high prevalence of sanitation related diseases such as diarrhoea in the country. Realizing this and other problems associated with poor access to sanitation, the World Health Organisation (WHO) issued the guidelines on the safe reuse of source separated human excreta [3].

Also, approximately $88 \%$ of diarrhoeal diseases are attributed to unsafe water supply, inadequate sanitation and hygiene [4]. Diarrhea and water-borne diseases are the leading causes of mortality and morbidity in developing countries including Nigeria [5]. Improved sanitation can contribute towards the control of infectious conditions, such as diarrhoea and dysentery [6]. However, a recent report by UNICEF [7] estimated that 34 million people lack toilets and 
resort to open defecation in Nigeria. Globally, there are many types of toilet designs, some of these are dry systems and others are water based. According to Bracken and Kvarnstrom [8], a sanitation system should consider the users of all parts of the system, along with the collection, transport, safe disposal and treatment of human excreta [9].

On maintenance of cleanliness of environment in the study market, the market association employs private "environmental sanitation task force" to ensure cleanliness and undertakes supervision of market sanitation. Most markets in Nigeria are devoid of formal institutional sanitation facilities and when people are pressed to use the toilet, they resort to open defecation and urination; at close distances where minimal privacy is guaranteed. However, in most of the few markets where sanitation facilities abound, they are poorly managed [10]. Hence, the need to evolve a sustainable and conservative approach to solving the problem in Nigerian markets through sustainable and integrated waste management techniques. Though, there are no composting toilets in Nigeria, the authors had seen and had experiences from other countries particularly in Europe where dry sanitation systems have been successfully utilized. Communities in Europe are fairly educated with less taboos who can adapt to the new technologies with ease. Since the composting toilet is being planned for Nigeria and other African countries which are known for their multi-cultural and multi-religious population, the first task has been whether people will accept a dry toilet system without using water for anal cleaning? Also, whether the composting toilet can serve large communities like market, schools and motor parks where the usage is rather rough.

Composting toilet or Urine Diversion Dry Toilet (UDDT) is a sustainable technology that processed excreta into usable fertilizer for soil amendment. The system is designed and built to be comfortable for users, safe, sustainable and ideal for rural and peri-urban homes, parks and farm houses. The toilet does not use water to flush excreta, devoid of odour, flies or other diseases vectors and does not contaminate soil compared to septic tank, soil-based disposal systems. Instead it recycles human wastes and turns them into nutrient rich compost, thus giving value to the excreta through processing and reuse as a soil conditioner. This type of toilet is economically and socially viable [11] and therefore has potential for sustainable, value- ladden excreta management in Nigerian markets.

\section{Materials and Methods}

\subsection{Description of the Study Area}

Kuje market was established by the Federal Capital Territory, Abuja for four area councils as a source of revenue generation. The area councils are: Abuja Municipality, Kuje,
Gwagwalada and Abaji (Figure 1). At the time of carrying out this study there were 199 formal shops in Kuje market, owned and managed by the Local Government, comprising 145 lock up shops and 44 open stalls. In the market, there were many sections and units, depending on types of business, though not all the sections were unitary since some areas had mixed marketers selling varieties of goods. There was open access at any time of the day as the market was not fenced. The market had no opening or closing time periods and many people lived in the market, against standard practice. There was no public water supply facility and the market is served by three, fee-paying toilet facilities located at close distances and managed by private individuals.

\subsection{Data Collection Procedure}

This study was carried out between December, 2013 and January 2014. The study utilized a total sampling approach where the owners of all 199 lock-up and open stalls in Kuje market were enrolled and participated in the study. Besides, the study focused on opinion leaders who occupied key decision making positions in the market, from Kuje LGA council to the main market association and individual unit associations in the market through Key Informant Interviews (KIIs) and Focus Group Discussions (FGDs) and semi-structured, interviewer-administered questionnaire. Two focus group discussions were held with male and female representatives of the marketers to discuss perception of the existing toilet facilities and their preferences on the planned waterless toilet. Key informant interviews were conducted on the market chairman, market association union representative, women leader of the general market association union and two private toilet operators. Findings from KIIs and FGDs were used to develop the questionnaire.

The questionnaire had sections on socio-demographic characteristics of respondents, water supply and sanitation practices, knowledge and awareness about toilet and hygiene, information and communication sources, toilet use features, hygiene, willingness to pay, preference of the toilet design and reasons that could prevent them from using the dry toilet in Kuje market when constructed. Results of FGDs and KIIs were transcribed and transcripts were analyzed with Atlas.T1 software using primary and secondary codes and project themes as the basis for analysis. The quantitative data was analysed by Statistical Package for Social Sciences (SPSS) version 16 software. The findings were summarized with descriptive statistics for continuous variables while frequency and percentages were used for categorical variables) and inferential statistics (chi square, Odd ratio and Confidence Interval) were used to test differences among selected variables). Bar chats was also used for visibility of some results. The response rate to the questionnaire administered was $98.9 \%$. 


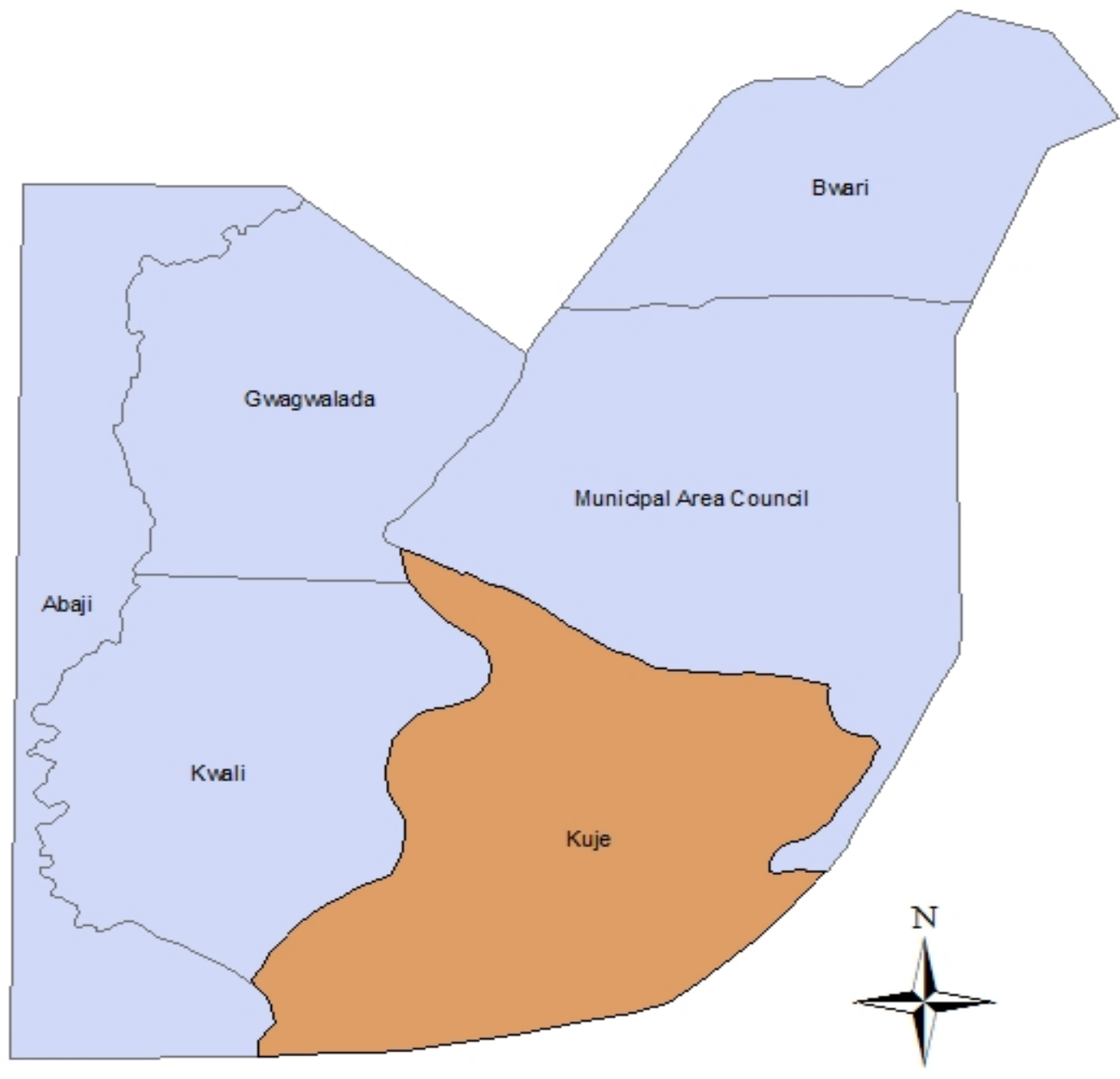

\section{Legend}

Kuje Area Council

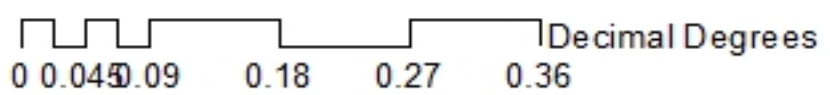

\section{FCT Area Councils}

Figure 1. Map of the Federal Capital Territory showing Kuje LGA where the study market is located

\section{Results and Discussion}

\subsection{Socio-demographic Information of Respondents}

Table 1 presents the socio-demographic characteristics of respondents (stalls owners) that participated in the study. The mean age was $34.3 \pm 9.7$ years while the minimum and maximum ages were 18 and 70 years, respectively. Many $(55.8 \%$ ) were females, $77.2 \%$ were Christian, $82.2 \%$ were married while $52.8 \%$ belonged to Igbo ethnicity. The mean number of years of experience in trading business was $7.1 \pm$ 6.8 years. Most of the respondents $(86.5 \%)$ had between $1-5$ members in their stalls and $23.4 \%$ had between 6-10 members.

\subsection{Existing Water, Sanitation and Hygiene Conditions in the Market}

The sources of water used by respondents in the market were: hand dug well $(11.7 \%)$, borehole (37.6\%), water vendor $(41.6 \%)$ and sachet water $(9.1 \%)$. According to the KII with the market manager, "If there is any crises that needs attention, the issue will be discussed with the market association Chairman, who called for meeting of traders and liaised with the LGA directly depending on the severity and seriousness of the issue at hand". Within the last one month, respondents received information on appropriate use of toilet and hygiene through various channels: television $(16.2 \%)$, radio $(14.7 \%)$, health workers $(8.1 \%)$, market meetings $(6.6 \%)$ and town announcers $(5.6 \%)$, among others (Figure 2). 
Table 1. Socio-demographic information of respondents

\begin{tabular}{|c|c|c|}
\hline Variable description & Frequency & Per cent \\
\hline \multicolumn{3}{|l|}{ Age (years) $(n=197)$} \\
\hline$\leq 20$ years & 11 & 5.6 \\
\hline $21-30$ years & 74 & 37.6 \\
\hline $31-40$ years & 72 & 36.5 \\
\hline $41-50$ years & 28 & 14.2 \\
\hline$\geq 51$ years & 12 & 6.1 \\
\hline \multicolumn{3}{|l|}{ Gender $\quad(n=197)$} \\
\hline Male & 87 & 44.2 \\
\hline Female & 110 & 55.8 \\
\hline \multicolumn{3}{|l|}{ Experience in trading (Years), $(\mathrm{n}=197)$} \\
\hline$<10$ years & 143 & 72.6 \\
\hline $10-19$ years & 45 & 22.8 \\
\hline $20-29$ years & 07 & 3.6 \\
\hline$\geq 30$ years & 2 & 1.0 \\
\hline \multicolumn{3}{|l|}{ Ethnicity $(\mathrm{n}=197)$} \\
\hline Yoruba & 30 & 15.2 \\
\hline Igbo & 104 & 52.8 \\
\hline Hausa & 35 & 17.8 \\
\hline Others & 28 & 14.2 \\
\hline \multicolumn{3}{|l|}{ Marital status $(\mathrm{n}=197)$} \\
\hline Married & 162 & 82.3 \\
\hline Single & 29 & 14.7 \\
\hline Others (divorced/separated/widow) & 6 & 3.0 \\
\hline
\end{tabular}

Source: Field data, 2014.

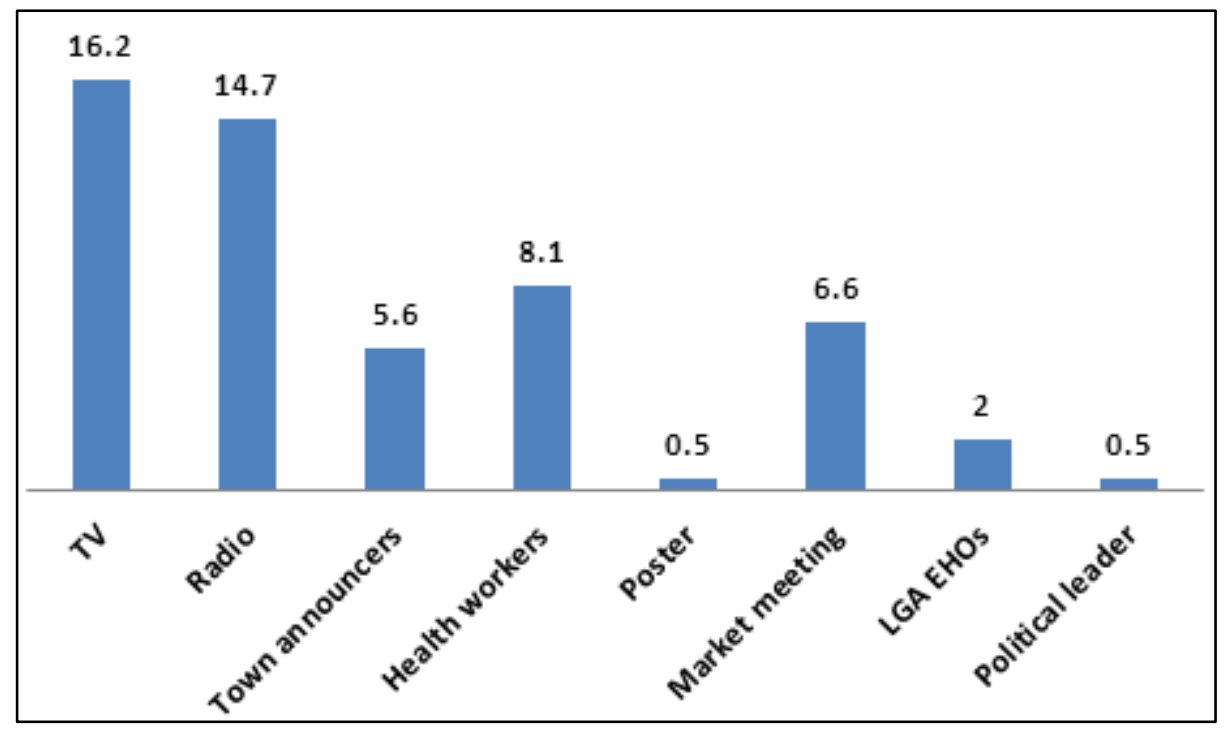

Figure 2. Sources of information on sanitation and hygiene

The KII with the Market Manager revealed tha, 'the market participates in the nationwide end of the month sanitation exercise (last Saturday of the month) and engages labourers to clean the market' while the female FGD concluded by saying that "Every open and lock up stall contributes NGN 100 (one hundred naira only exchange rate $1 U S D=N G N 195)$, once in a month for the cleanliness of the market. The market association has an agreement with a private group 'Environmental Group' that cleans the market, from time to time". Individual stalls owners 
collect their refuse, contract a vendor to transport and dispose at the general waste dump site, located within the market for a fee. In extreme situations, discussants said that, 'the general market Association Chairman informs the LGA through the market Manager to send vehicles and caterpillars for evacuating solid waste from the waste dumps in the market'.

There were three existing toilets in the market, comprising two traditional pit toilet types and one pour flush toilet. Each of them provides excreta disposal, bathing and urination services to variety of customers within and around the market. However, there was poor management of the toilets (with odour and dirty surroundings) which may compromise the patronage by the users. According to a toilet operator, 'Our customers are mostly males and only one out of 10 users is a female'. Another toilet operator said, 'just very few of females use the toilet, not up to 30 every week'. Women do not patronize the toilet because they defecate in nylon, and throw into the solid waste dung hill in the market instead of patronizing the privately operated toilets. At the moment of this study, each of the three toilet systems charged customers $\mathrm{N} 30, \mathrm{~N} 20$ and $\mathrm{N} 10$ for defecation, bath and urination, respectively.

Many of the respondents $(69.0 \%)$ used VIP toilet. Other types used by respondents were traditional pit toilet $(19.3 \%)$ and open defecation $(9.7 \%)$. The use of open defecation may probably be due to low cost $[12,13]$ and inconvenience in using existing toilets by respondents. Also, $15 \%$ of the global population mostly from Africa and Asia practice open defecation [14-16]. Furthermore, the urination habit of respondents revealed that only $38.1 \%$ respondents used the toilets while others $(61.9 \%)$ used open and hidden locations for urination. Table 2 reveals the reasons why many respondents abstained from using existing toilets in the market. Many of them said that they were poorly maintained and unregulated by the environmental sanitation unit of the LGA.

Table 2. Reasons for non-use of existing toilets in the market

\begin{tabular}{ccc}
\hline Description statements $(\mathrm{n}=197)$ & Frequency & Per cent \\
\hline Make me susceptible to disease & 40 & 20.3 \\
Poorly maintained and cleaned & 113 & 57.3 \\
Odour/smell & 4 & 2.0 \\
No Response & 40 & 20.3 \\
\hline
\end{tabular}

Source: Field data, 2014.

Challenges experienced by toilet operators against the maintenance of the existing toilets were: defecation around the toilet plat form, faecal drops around the squatting holes, uncoordinated use of water by the users, abuse of toilet by users; some users paid to use the bath but end up defecating, wrap faeces in nylon and hide it inside the bathroom, to avoid payment for the toilet and inadequate staff as the work was too much for a single person. Despite the enumerated challenges, the operators were happy with their job because since they made enough money and met their needs. Table 3 shows other sanitation and hygiene practices in the market. Majority $(77.7 \%)$ were fond of using potty because the toilet is too far $(8.6 \%)$ or for other reasons. More than half $(60.4 \%)$ used tissue for anal cleansing and few $(2.0 \%)$ used paper. Majority of the respondents also practiced hand washing with soap $(73.1 \%)$ while some $(5.0 \%)$ did not washed hand after defecation.

Table 3. Sanitation and hygiene practices of respondents

\begin{tabular}{ccc}
\hline Variables description & Frequency & Per cent \\
\hline Use of potty for defecation $(n=197)$ & \\
Yes & 44 & 22.3 \\
No. & 153 & 77.7 \\
Reasons for using potty for defecation $(n=44)$ & \\
Convenience & 18 & 9.1 \\
Toilet too far & 17 & 8.6 \\
Diseases prevention & 9 & 4.6 \\
Anal cleansing materials after defecation $(n=197)$ \\
Water & 74 & 37.6 \\
Tissue & 119 & 60.4 \\
Paper & 4 & 2.0 \\
Hand washing practice $(n=197)$ & \\
Water only & 48 & 24.4 \\
Water and soap & 144 & 73.1 \\
None & 5 & 2.5 \\
\hline
\end{tabular}

Source: Field data, 2014.

\subsection{Respondents Practices on Selected Sanitation and Hygiene Variables at Home and in the Market}

Table 4 and Table 5 showed the association between selected variables when respondents were at home and when they are in the market where they pligh their trade daily. There was no significant difference between the type of water used in the market and those use at home by respondents $(\mathrm{P}=0.08)$, in contrast to toilet $(\mathrm{P}=0.0001)$ and handwashing practice $(\mathrm{P}=0.0001)$, respectively. In the same manner, the odds of respondents using sanitary toilet for excreta disposal, and for washing hands in the market, when compared to their practice when at home were seven and twenty eight, respectively. moreover, there was a significant different between anal washing materials used by respondents at home and in the market $(\mathrm{P}=0.0001)$, as shown in Table 5. The above results showed the differences in practice when respondents were at home and in the market, probably due to paucity of facilities and poor status and maintenance conditions of the existing sanitation and hygiene facilities in the market when compared to their homes. 
Table 4. Association between selected practice variables when respodents are at home and in the market

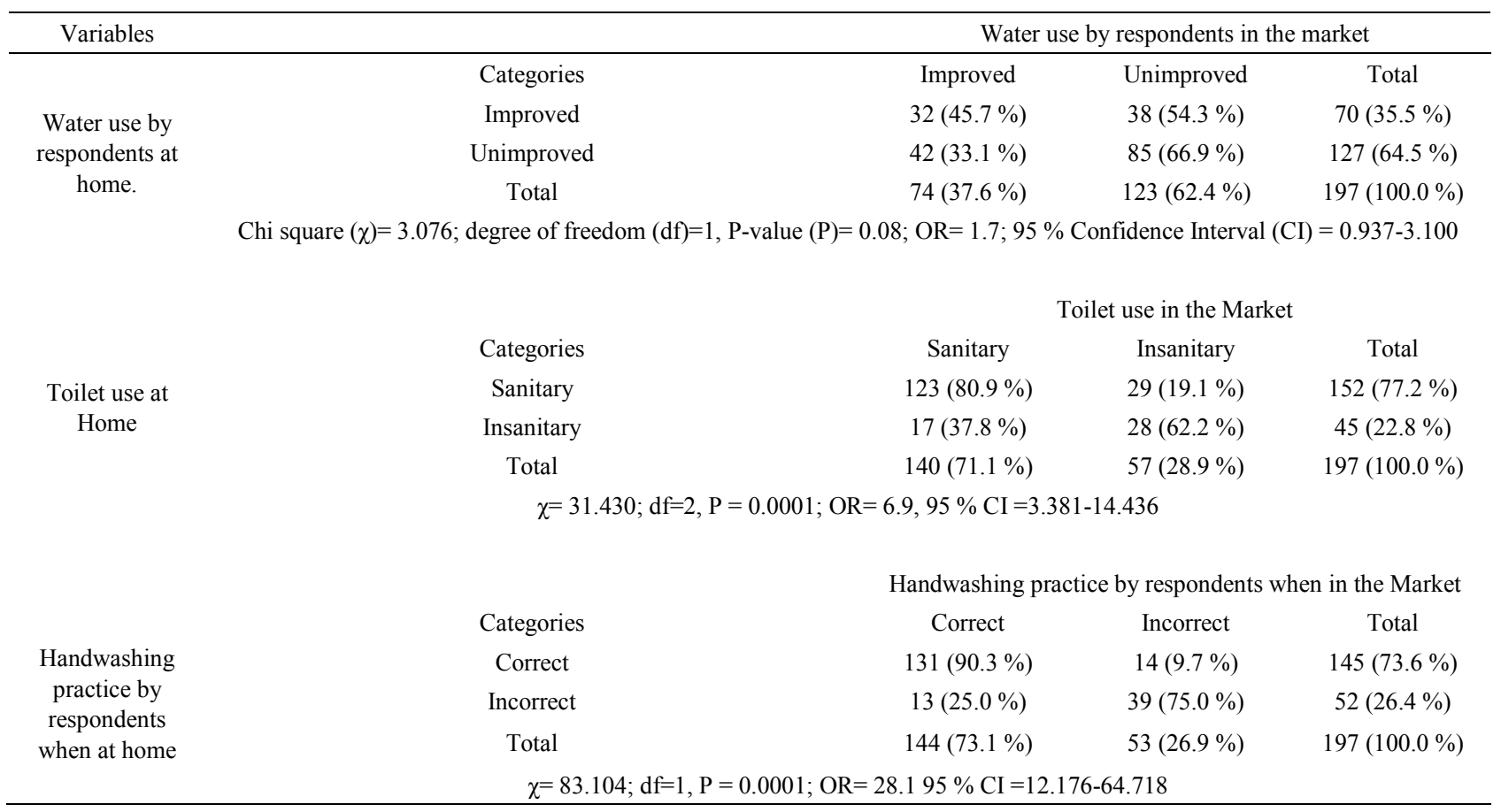

Source: Field data, 2014.

Table 5. Comparison of anal cleansing materials used by respondents at home and in the market

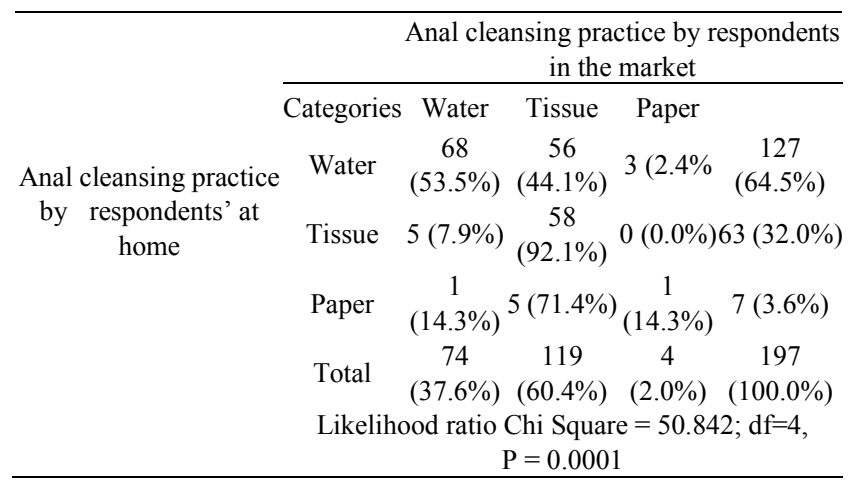

Source: Field data, 2014.

The study revealed that socio-demographic characteristics of respondents, such as ethnicity $(\mathrm{P}=0.812)$, religion $(\mathrm{P}=0.650)$, sex $(\mathrm{P}=0.680)$ and marital status $(\mathrm{P}=0.510)$ were not significant predictors of toilet use in the market. However, the multiple regression analysis showed that queuing (odds ratio $[\mathrm{OR}]=29.1,95 \%$ confidence interval $[\mathrm{CI}]=1.09-5.24, \mathrm{P}=0.001)$ and non-satisfaction with the state of the toilets in the market (odds ratio $[\mathrm{OR}]=18.7,95 \%$ confidence interval $[\mathrm{CI}]=.000, \mathrm{P}=0.001$ ) were the significant predictors of non-use of toilets in the market, indicating that a history of queuing to use the toilets in the market had a 29 and 19 folds likelihood of respondents seeking alternative toilets outside the market when pressed, to those available in the market, respectively. Now, if the dry toilets can remove these challenges, then use of the installed toilet would be enhanced.

\subsection{Awareness and Perception of Dry Toilet in the Market}

None of the stakeholders, except the Chairman of the Market Association had previously heard about waterless toilet. Some of the women that participated in the FGD said, 'No, we have not heard about it. However, there is no way you can go to the toilet without using water'. They were of the opinion that: the dry toilet would compete with other existing toilets which would lead to the better performance of the existing toilets and improved sanitary conditions in the market. Most respondents $(80.7 \%)$ were willing to pay and use the newly built dry toilet in the market because of aesthetics $(28.9 \%)$, clean $(21.8 \%)$ and disease prevention $(6.6 \%)$.

\subsection{Willingness to Pay for Toilet Use in the Market}

The study showed that most respondents, 159 (80.7\%) were willing to pay for use of safe toilets in the market. Though reconnaizance showed that respondents paid N30, N20 and N10 for using the toilets for defecation, bath and urination. The quantitative findings were in agreement with the current situation since the study further showed that if the toilets are well maintianed, the respondents were willing to pay up to N10, N20 and N20 for urination, bath and toilet use for faceal passage respectively. However for faeces management, $30(15.2 \%)$ and (14 (7.1\%) among the respondents were willing to pay up to N30 and even more, respectively as shown in Table 6. 
Table 6. Users' willingness to pay for dry toilet use in the market

\begin{tabular}{|c|c|c|c|c|c|c|}
\hline \multirow{2}{*}{$\begin{array}{c}\text { Amount Willing To Pay per } \\
\text { single use (NGN) }\end{array}$} & \multicolumn{2}{|c|}{ Urination $(\mathrm{n}=141)$} & \multicolumn{2}{|c|}{ Bath $(\mathrm{n}=119)$} & \multicolumn{2}{|c|}{ Defecation $(n=130)$} \\
\hline & Frequency & Percent & Frequency & Percent & Frequency & Percent \\
\hline N01-N10 & 102 & 51.8 & 26 & 13.2 & 23 & 11.7 \\
\hline N11-N20 & 34 & 17.3 & 50 & 25.4 & 63 & 32.0 \\
\hline $\mathrm{N} 21-\mathrm{N} 30$ & 04 & 2.0 & 27 & 13.7 & 30 & 15.2 \\
\hline$\geq \mathrm{N} 31$ & 01 & .5 & 16 & 8.1 & 14 & 7.1 \\
\hline
\end{tabular}

Source: Field data, 2014.

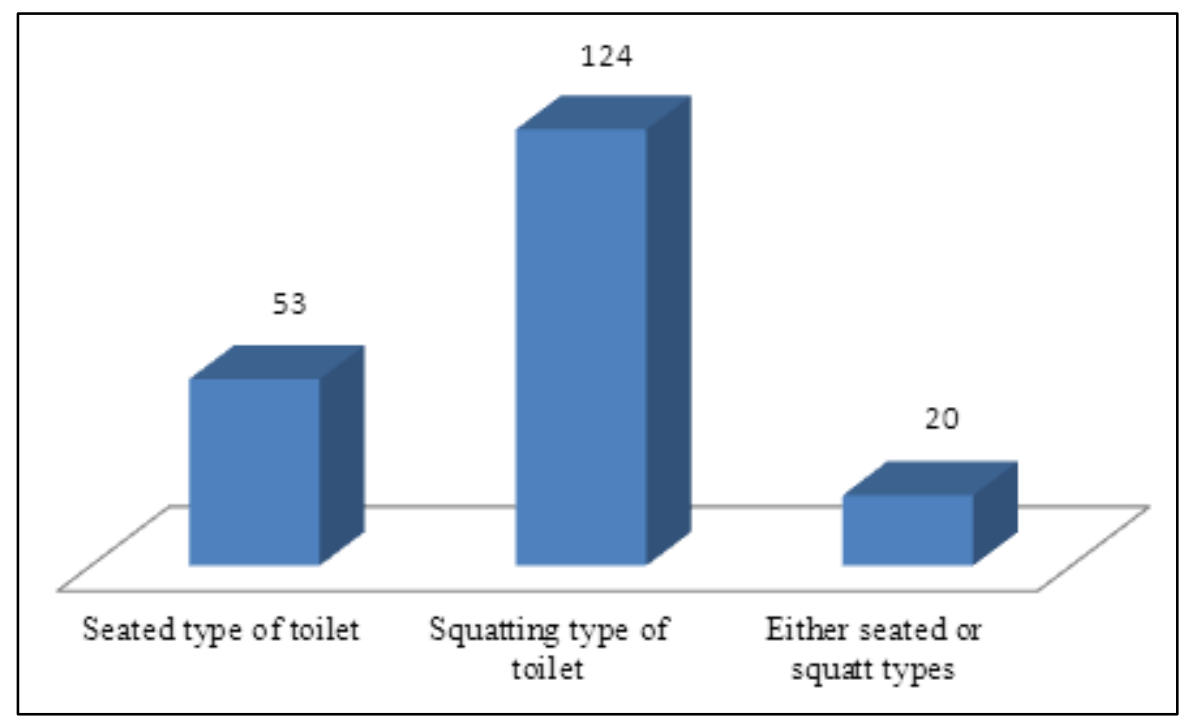

Figure 3. Preference of toilet type by respondents in the Kuje main market

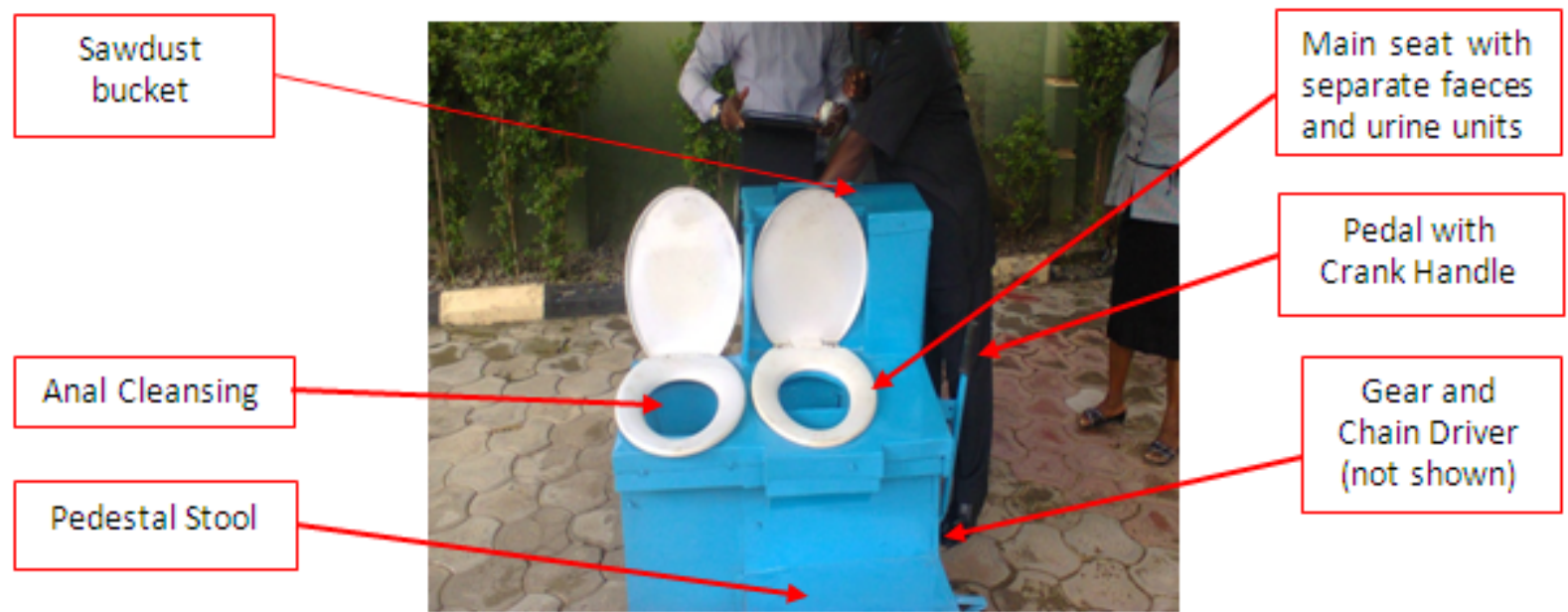

Figure 4. Features of the dry composting toilet

\subsection{The Toilet Unit and the Facility Design}

Most respondents preferred the squating toilet type $(62.9 \%)$ while others were seated $(26.9 \%)$ and eitherof the two types (10.2\%) (Figure 3). Figures 4 presents the features of the dry toilet and Figure 5 shows other components installed in the complex for converting faecal sludge to organic fertilizer.

Most of the available urine diversion and dry toilet technologies do not make any provision for anal cleaning with water thus preventing access to some culturally sensitive sections in the communities. Thus a new idea introduced in Kuje market, Abuja, Nigeria was a twin bowl system whereby, a user may just move his bottom after defecation in the main bowl to the next bowl where a small volume of water is allowed to pass through a spray hose operated by pressing a knob. The bowl for devication was further divided into 2 units (one for faeces and the other for urine) so as to divert urine into urine collection tank through a thick platic pipe. In most of the European and Asian designs, the faecal matter mixed with saw dust or ash is allowed to remain in the compost tank below the toilet. In Nigeria such a design is not practicable particularly for public use like a market where users may also discharge 
various pathogens including helminths in the defecation process. We felt that it is necessary to move swiftly the faecal matter into a primary composting pit where the faecal material mixed with the saw dust/ash will be given adequate time for degradation of organic matter and then allowed to stabilize which in turn also results in considerable reduction and destruction of the pathogens.

The uniqueness of this toilet complex is that dry toilet was experimented for the first time in Nigeria at a community level. The toilet has eight compartments ( 4 for men and 4 for women); sawdust or ash produced in the market or neighbourhood is used to make compost within primary tank and other features are incorporated to stabilize the compost (Figure 4). A pre-determined quantity of sawdust or ash is added to faeces by pressing the pedal at once. Ash has the added advantage of raising the $\mathrm{pH}$ which is good for destroying the pathogens and prevent odour. The faeces-sawdust/ash mixture is propelled into a primary tank and left there for some weeks (time depends on the amount of faecal matter discharged). It is thereafter manually transferred into a central processing or secondary composting area inside a shed and monitored till full maturity. At this stage the compost will attain the required consistency and quality.

The design also incorporates the use very little water for anal cleaning for those people culturally sensitive which is drained into a soak away pit built in the facility. Urine is harvested, stored in a separate tank and supplied to farmers who form a significant stakeholder group in the market as organic manure. The facility management has necessary machinery to oversee the urine sale for farming populations. In addition, the women's urinal unit has a menstrual pad disposal outlet with a sliding cover and when the pad is dropped, gets into a specially designed incinerator unit where the pads are burnt in situ at regular intervals. The faeces bucket is detarchable to ensure a proper cleaning into anal cleaning bucket with water and disinfectant by trained attendants in the complex.
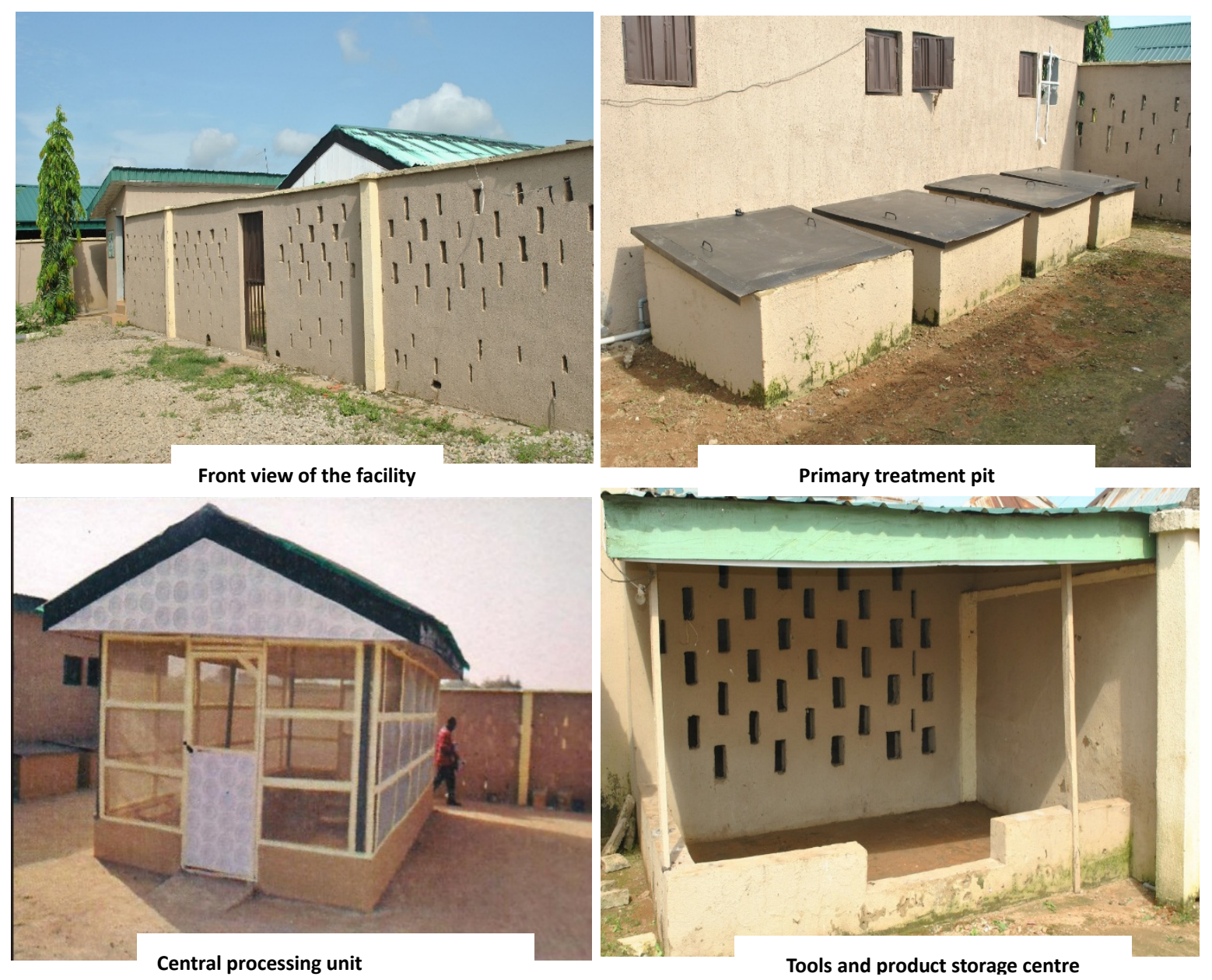

Figure 5. Sections of the toilet complex 


\section{Study Limitations}

The study ommitted visitors perceptions on the planned construction and installation of dry sanitation systems. The study utilized mix methods approach, which means findings from the use of questionnaires is prone to response bias.

\section{Conclusions}

The traders at Kuje market has limited access to improved water supply and adequate sanitation as they had been practicing open defecation. They exhibited poor toilet maintenance culture but showed high level of hand washing hygiene practices. A novel urine diversion dry toilet was designed and installed in the market where the knowledge of the traders was very low. The design was developed based on the users' perceptions and expectations as obtained prior to the construction. It is women friendly where gender privacy and special needs were taken into consideration. The facility is ecofriendly as it incorporated toilet, urinal, bathroom, menstrual pad disposal, urine and water used for anal cleaning are separately stored in a special tank and soak away pit, respectively. Separate male and female caretakers maintain the facility. The faecal matter is converted into compost and supplied to the farmers who patronize the market along with the urine harvested. It serves as a model for other public institutions where sanitation is compromised. The stakeholders should play very active role in maintaining the facility for sustainability.

\section{Acknowledgements}

The authors acknowledge the financial support of Grand Challenge Canada in the execution of this work. Frantic efforts exerted by Mr. Adejumo who helped in data analyses. We also thank the staff of Women Friendly Initiative (WFI) for the monitoring and supervisory roles during the course of executing this project.

\section{REFERENCES}

[1] WHO (World Health Organization)/UNICEF. Progress on Drinking Water and Sanitation: 2012 Update. (Geneva and New York WHO/UNICEF Joint Monitoring Programme for Water Supply and Sanitation). Accessed on 10/8/2016 from: http://www.unicef.org/media/files/JMPreport2012.pdf

[2] WHO and UNICEF. "Meeting the MDG Drinking Water and Sanitation Target: A Mid-Term Assessment of Progress." 2004. Accessed on 18/08/2016 from: www.who.int/water_sa nitation_health/monitoring/jmp2004/en/

[3] WHO. Guidelines for the Safe Use of Wastewater, Excreta and
Grey water. Volume IV - Excreta and Grey water Use in Agriculture. 2006. Accessed on 02/08/2016 from: http://www.who.int/water_sanitation_health/wastewater/gsu weg4/en/index.html

[4] WHO. Water Sanitation and Hygiene, Facts and Figures, March 2004. WHO, Geneva. Accessed on 30/07/2016 from: http://www.who.int/ water sanitation health/publications /factsfigures04/en/

[5] WHO/UNICEF Joint Monitoring Program me for Water Supply and Sanitation, Global water supply and sanitation assessment, report, 2000. WHO, Geneva. Accessed on 12/08/2016 from: http://www.who.int/water sanitation health/monitoring/jmp2000.pdf

[6] F. Greaves and L. Webster. Sanitation and the Millennium Development Goals. 2007. Accessed on 12/08/2016 from: www.tilz.tearfund.org/.../Sanitation+and+the+Millennium+ Development + Goals.htm.

[7] UNICEF. Lack of toilets dangerous for everyone. 2012. Accessed on 13/08/2016 from: http://www.unicef.org/media/ media_77952.html

[8] P. Bracken and E. Kvarnstrom. Making sustainable choices the development and use of sustainability oriented criteria in sanitary decision making. Paper presented at the 3rd International Conference on Ecological Sanitation, 23 -26 May 2005, Durban, South Africa. 2005.

[9] J. O. Drangert. Fighting the urine blindness to provide more sanitation options. Water SA, Vol. 24, No. 2: 157-164. ISSN 0378-4738. 2008.

[10] DFID. Water: Knowledge and Research: Department of International Development Issue 18, p12. 2004.

[11] G. Anurag. EcoSan toilets - an alternative to conventional sanitation in vulnerable locations. 2014. Accessed on 14/08/2016 from: http://www.wateraid.org/news/news/ecosa n-toilets

[12] J. Bartram, K. Charles, B. Evans, L. O'Hanlon, and S. Pedley. Commentary on community-led total sanitation and human rights: should the right to community-wide health be won at the cost of individual rights? Journal of Water and Health Vol 10, No.4: 499-503. 2012.

[13] World Bank.. How We Classify Countries. 2013. Accessed on 10/08/2016 from: http://data.worldbank.org/about/country-classifications

[14] S. Cairncross, C. Hunt, S. Boisson, K. Bostoen, V. Curtis, C.H.I Fung, and W. Schmidt Water, sanitation and hygiene for the prevention of diarrhea. International Journal of Epidemiology. Vol 39: 93-205. 2010.

[15] N. Jain. Getting Africa to Meet the Sanitation MDG: Lessons from Rwanda. Washington, DC: World Bank Water and Sanitation Program. 2011. Accessed on 10/08/2016 from: http://www.wsp.org/sites/wsp.org/files/publications/wsp-rwa nda-sanitation-lessons.pdf

[16] WHO (World Health Organization)/UNICEF. Progress on Drinking Water and Sanitation: 2013 Update. (Geneva and New York WHO/UNICEF Joint Monitoring Programme for Water Supply and Sanitation). 2013. Accessed on 10/08/2016 from: http://www.unicef.org/media/files/JMPreport2013.pdf 